\title{
Civic, citizenship and rhetorical education in a rapidly changing world
}

\author{
Janja Žmavc \\ Plamen Mirazchiyski
}

T

oday's youth are tomorrow's future. A truism, which is quite often used in different context, including education. Besides being well educated in core subjects, we expect that the youth of tomorrow's future will also be informed and knowledgeable citizens, critical and active participants in social and political processes that understand and master principles of persuasive language use. Undoubtedly, civic, citizenship education and rhetoric - if we summarize the above description with these notions - are highly interrelated topics that permeate modern education in terms of its aims and goals. This is the reason why we decided to draw up a joint issue and point out some features of the contemporary development of civics, citizenship and rhetoric as independent educational topics as well as their pedagogies, and in particular, to highlight close conceptual and historical links between the fields, which should be kept in mind when we develop curricula, educational programs, specific subjects with goals such as "knowledgeable citizens", "critical thinkers", "active participants".

Although the goals of civic and citizenship education seem to be more or less consistent, the content and organization take a variety of forms in different subjects across the countries around the world. Besides its variety, in the last decades some serious challenges have been faced: (I) social and political issues are not pertinent to particular countries only, but have international reverberations; (2) the countries and the entire world are not static, but change rapidly; and (3) the mass migration of people. 
One of the major challenges to civic and citizenship education is the globalization of the modern world and the national boundaries on the one hand and the national boundaries of the curriculum on the other. While the nation state is easier to understand and control, the global communities are less predictable. The national curriculum is more focused on the national structures and issues, emphasizing less the international ones (Reynolds, 2012). Of course, this is expected since we all (even under the European Union) still live in nation states with their own cultures and specific traits of the social and political systems; this is related to the national curricula on the subject. In addition to this issue, there have been worldwide rapid changes affecting the entire planet with repercussions on regional, country and local levels. With the advance of technologies in the last decades, these repercussions have become instant and the changes apply much faster than they used to do in the past. A new form of citizenship, the digital one, came about - taking part in internet activities affects how we think, communicate and participate in society, which results in adopting new perspectives towards the self, others, the communities and the entire world. This process makes the boundaries between online and offline activities more transparent for the more digitally-oriented generations, making the Internet an empowering space for active engagement in civic life in a way that is closely related to the traditional forms, and even going beyond them (Choi, 2016). In addition, there is the issue of the mass migration of people - some of them as a normal consequence of the globalizing world, others as refugees from war zones and chaos. This also complicated the development of civics and citizenship education due to the rise of multiple issues like populism and nationalism around the world (Banks, 2017).

Rhetorical education, on the other hand, has an enviably long tradition when it comes to facing social changes. With more than 2000 years of perpetual ups and downs with regard to its reputation, rhetoric is a constantly present topic throughout the education in Europe and America and offers an important insight into how to make sense of educational content in a concrete, time and place specific socio-cultural context (Glenn, Lyday and Sharer, 2009).

Commonly defined as the art of successful (public) persuasion, rhetoric is closely associated with the development and conception of democracy and citizenship culture in the European historical and cultural space with its origin in the Greek polis, Athenian democracy and Roman res publica. Namely, rhetoric was never (only) an art of speaking well, as it is still perceived in the everyday notions as well as in certain academic discourses, which emphasise merely its long tradition in writing instructions 
and literary composition. As a complex discipline, rhetoric should primarily be understood in the classical Greco-Roman social perspective, that is as a civic competence, which is crucial for an individual's successful active social engagement. With its clear inscription of the relation of language and power in a specific cultural moment, rhetoric thus represents an important, yet controversial topic of education. For example, despite the ideal general orientation of rhetorical education to shape all citizens for public participation (which for the most part of history represented men of the upper class who were trained for public leadership positions), the question of "who should receive rhetorical education, in what form, and for what purpose" even nowadays makes it a slippery concept in terms of a theory or a practical application (Glenn, 2004, p. viii).

It should not come as a surprise, that modern theories of rhetoric and rhetorical education see rhetorical education as one of the key elements of modern citizenship education and they advocate for a systematic teaching of rhetoric, which includes modern conceptualizations of (active) citizenship, democracy, interculturality, etc. (Danisch, 20I5; Ferry, 2017; Kock and Villadsen, 2012, 2017). On the other hand, any modern rhetorical education that is firmly grounded on the classical perspective provides a support for the humanities paradigm, which opposes the current profit-oriented education (Nussbaum, 2012) and places arts and humanities (and rhetoric along with them) at the centre of modern education for democracy. Consequently, as it has been known to happen many times before in the history of education (Conely, 1994), the role and importance of rhetoric as an educational topic is again being deliberated in the context of various education systems in Europe, either at the level of integration of rhetoric in the National Curricula as a part of existing subjects (Aczel, 2019, Bakken, 2019; Kjeldsen and Grue, 2011), or designing (new) educational content or programmes (Dainville and Sans, 2016; Z̆agar $\breve{Z}$. et al., 1999/2004; Žmavc et al., 2018) or at the level of raising awareness of the importance of mastering rhetoric as a part of 21st century competence and skills (Holmes-Henderson, 2016). However, rhetorical education can hardly be reduced solely to the traditional composition perspective or its current social and civic aspects. There is also the "interactive" perspective of rhetoric, which originates in the well-known classical conceptions of public persuasion as a communicative act between the speaker, the audience and the speech. Thus, as a communication practice, rhetoric in the context of education should be seen (also) as transversal, a transferable skill that is relevant in different school and learning situations. Its role, within the pedagogical process, is particularly important since mastering rhetorical and argumentation principles influences especially the success 
of knowledge co-creation, the effectiveness of the pedagogical process, the dynamics of interpersonal relationships and the formation of self-image of all participants in the pedagogical process (Žmavc, 2016).

We have briefly outlined the main points that concern contemporary civic, citizenship and rhetorical education. Multiple articles in this special issue address some of them in a much more thorough manner, opening new perspectives on how to see their role in contemporary education and also pointing out problems that arise with modern conceptions and definitions of historically grounded concepts, notions, and ideas such as rhetoric, persuasion, democracy, citizenship, critical thinking, ethics etc.

In the first part of the publication, the articles focus on civic and citizenship education. Contributions from Ines Elezović and Marinko Banjac discuss the civic and citizenship curriculum and the acquisition of civic and citizenship knowledge in Croatia and Slovenia respectively. The articles review the context of teaching and learning the subject at school. The article from Ines Elezović titled Civic and citizenship education in the Republic of Croatia: 20 years of implementation brings the results from the IEA's International Civic and Citizenship Education Study (ICCS) 2016 within the scope of the overview of the developments in the subject in Croatia since 1995. In his article Knowledge on political participation among basic school pupils: a look at the results from the National Assessment of Knowledge in the course Patriotic and Citizenship Culture and Ethics in the 2018/2019 School Year Marinko Banjac uses the results of knowledge of political participation from the latest Slovenian national study of the $\mathrm{Pa}$ triotic and Citizenship Culture and Ethics subject (part of the National Assessment of Knowledge).

In the article titled Expected political participation and demographic changes in Europe Mojca Rožman and Diego Cortés aim to investigate whether the recent immigration-related demographic change in Europe can be associated with changes in expected political participation of young adults. The article uses Slovenian data from IEA's ICCS cycles conducted in 2009 and 2016 , as well as data from national statistics and voter turnout database.

The article Bullying of eighth graders in Slovenian primary schools (secondary analysis of ICCS 2016) from Špela Jarovnik, Plamen Mirazchiyski and Nada Trunk Sirca focuses on bullying at school, its frequency and relationship with contextual and background factors using data from the International Civic and Citizenship Education Study (ICCS) 2016. An interesting finding from this study, which deserves further research, is 
that students who have higher civic knowledge tend to be bullied less often compared to the less knowledgeable students.

In the second part of the publication, four authors discuss rhetoric and its social (i.e. civic and educational) role from various theoretical perspectives. They also present their development of teaching models and practices, as well as explore the role of rhetoric in the context of education for active citizenship. The reading of these articles shows that we can still talk about the problems of diversifying the ever-heterogeneous field of rhetoric and rhetorical education, which accompanies this discipline from the time when Greek philosophers first exposed the problem of definition and scope of rhetoric. Despite the technological and social transformations that present a new challenge for rhetorical theories and practice, one thing may be certain: ancient (Ciceronian) ideas of the liberal education of the speaker-citizen as a pursuit of humanitas, which represents a process of a comprehensive (even personal) formation of the knowledgeable speaker, who only gives true meaning to the social benefit of rhetoric, is likely to remain one of the key needs even in modern times and societies.

In the article Debate at the Edge of Critical Pedagogy and Rhetorical Paideia. Cultivating Active Citizens Foteini Egglezou examines the concepts of rhetorical paideia and critical pedagogy through the analysis of the educational practice of debate and its possibility of cultivating active students-citizens. Debate as a multi-dynamic practice inevitably collides with rhetorical tradition on a conceptual and practical level. However, in order to be able to understand the differences between the two it is necessary to consider theoretical conceptions from the fields of rhetoric and argumentation, as well as historically grounded notions such as for example agon and dissoi logoi.

In the article $A$ Road to Rhetorica: Teaching Rhetoric as Social Sensitivity and Behaviour Petra Aczél offers her reconceptualization of rhetoric as the study of social sensitivity and behaviour. Revising the presently domineering Hungarian and Central-European educational practices of rhetoric, she presents a new three-layered teaching program of rhetoric that focuses on rhetorical sensitivity and includes three, in her opinion, of the most important skills for the $2 \mathrm{I}^{\text {st }}$ century: critical thinking, creativity and connecting/debating with others.

In the article titled Slovenian Experience with Rhetoric in Primary Schools Igor Ž. Žagar presents the unique situation of teaching rhetoric in Slovenia as a compulsory elective subject in primary school. As the main author of the first syllabus and the editor of the textbook, he explains the conceptual background of the structure of the syllabus and provides a general evaluation of its practical realisation. His findings repre- 
sent an important basis for the current revision of the syllabus, as well as for the introduction of rhetoric into secondary schools, which are a part of the project that has been going on at the Educational Research Institute since 2018 .

In the last article Experiences In Teaching Rhetoric As An Elective Course In Primary School Mojca Cestnik presents her extensive experience with teaching rhetoric in primary school. With a thorough description of didactic challenges, she argues for the need to teach rhetoric in primary school. She also outlines the important role of a teacher of rhetoric in primary school as a valuable expert in the area of pedagogical communication, who can enable better collaboration with teachers from the first to the ninth grade, as well as help properly unify the standards for oral performances at school.

Three reviews are included in this issue. The first one is a review of the book on "digital citizenship", issued by the Council of Europe (FrauMeigs et al., 2017). The book titled Digital citizenship education: Volume I - Overview and new perspectives provides extensive overview of 14 of the existing frameworks and definitions of the concept of digital citizenship and brings the link between the national policies on the topic of technological industry. It further explores the concept of digital citizenship and how the digital culture determines practices aiming at long-term experiential strategies which, in turn, contribute to participatory and inclusive approaches of digital citizenship education. A special focus of the book is the relationship between the social literacy and the digital environment. The book also provides recommendations for further development and implementation of strategies towards digital citizenship education.

A second review from Lucija Klun presents Peter Strandbrink's book Civic Education \& Liberal democracy: Making Post-Normative Citizens in Normative Political Spaces. The book exposes the inherent and (re)produced tensions in civic and citizenship education. These tensions, along with their collateral consequences, do not provide a sustainable way for implementing "canonized civics and citizenship" into the education process. Strandbrink provides detailed reasons for this, mainly because the authorities do not possess such power over teaching, processes and content, and, even if they would have, they could not control the input (teaching, content, etc.) and the output (acquired by the students). In this relation also comes the input from other disciplines, as well as the input from other contexts, i.e. beyond that of the educational system. Strandbrink points other issues, like the selection and framework of values, minimalist and maximalist conceptualization of civic and citizenship education and their consequences, among many other. 
A third review presents Mirjana Želježičss critical account of the book Rhetoric and the Global Turn in Higher Education (Minnix, 2018), which is an extensive study of the role of rhetorical education within global higher education in the USA. The monograph is built upon an appreciation of a strong bond between rhetorical education and power relations, arguing against viewing (global) higher education as a neutral movement, but rather as a site of conflict between competing ideologies and political interests.

\section{References}

Aczél, P. (2019) Teaching Rhetoric. A Proposal to Renew Rhetorical Education in Hungarian and Central European Contexts. Govor (In press).

Bakken, J. (2019) The integration of rhetoric into existing school subjects. Utbildning \& Demokrati 28(2), pp. 93-108.

Banks, J. A. (2017) Failed Citizenship and Transformative Civic Education. Educational Researcher 46(7), pp.366-377. https://doi. org/10.3102/0013189X1772674I

Choi, M. (2016) A Concept Analysis of Digital Citizenship for Democratic Citizenship Education in the Internet Age. Theory \& Research in Social Education 44(4), pp. 565-607. https://doi.org/10.1080/00933104.2 or6.1210549

Conely, T. M. (1994). Rhetoric in the European Tradition. Chicago: University of Chicago Press.

Dainville, J., and Sans, B. (2016) Teaching Rhetoric Today: Ancient Exercises for Contemporary Citizens. Educational Research and Reviews II(20), pp. 1925-1930. https://doi.org/I0.5897/ERR2016.3003

Danisch, R. (2015) Building a Social Democracy: The Promise of Rhetorical Pragmatism. Lanham, MD: Lexington Books.

Ferry, V. (2017) Exercising Empathy: Ancient Rhetorical Tools for Intercultural Communication. Nordicum-Mediteraneum I2(3), s.p. https:// nome.unak.is/wordpress/author/ferry/(27. II. 2019)

Frau-Meigs, D., O’Neill, B., Soriani, A., and Tomé, V. (2017) Digital citizenship education: Volume I - Overview and new perspectives. Strasbourg: Council of Europe.

Glenn, C., Lyday, M., and Sharer, W. (2009) Rhetorical Education in America. Tuscaloosa, Alabama: University Alabama Press.

Glenn, C., (2009) Rhetorical Education in America (A Broad Stroke Introduction). In Glenn, C., Lyday, M., and Sharer, W. (eds.). Rhetorical Education in America, pp. I-XVI. Tuscaloosa, Alabama: University Alabama Press. 
Holmes-Henderson, A. (2016) Responsible Citizenship and Critical skills in Scotland's Curriculum for Excellence: The contribution of Classical Rhetoric to Democratic Deliberation. In Carr, P., Thomas, P., Porfilio, B., Gorlewski, J. (eds.), Democracy and decency: what does education have to do with it?, pp. 213-228. Charlotte: Information Age Publishers.

Kjeldsen, J. E., and Grue, J. (eds.) (20II) Scandinavian Studies in Rhetoric. Rhetorica Scandinavica 1997-2010 https://www.retorikforlaget.se/ scandinavian-studies-in-rhetoric-introduction/ (27. I1. 2019).

Kock, C., and Villadsen, L. V. (2012) Rhetorical Citizenship and Public Deliberation. The Pennsylvania State University: Penn State University Press.

Kock, C., and Villadsen, L. V. (2017) Rhetorical citizenship: studying the discursive crafting and enactment of citizenship. Citizenship Studies 2I(5), pp. 570-586, DOI: 10.1080/13621025.2017.1316360

Minnix, C. (2018) Rhetoric and the Global Turn in Higher Education. San Jose: Palgrave Macmillan.

Nussbaum, M. C. (2012) Not For Profit. Why Democracy Needs Humanities. Princeton: Princeton University Press.

Reynolds, R. (2012) Civics and Citizenship Education in Its Global Context: The Complexity of Global Citizenship Dialogues. Education Sciences 2(4), pp. 190-192. https://doi.org/10.3390/educsci2040190

Žagar, Ž., I., Močnik, R., Pešec Zadravec, R., and Pavlin, M. (1999) Učni načrt. Program osnovna šola. Retorika [Elektronski vir] https://www.gov. si/assets/ministrstva/MIZS/Dokumenti/Osnovna-sola/Ucni-nacrti/ izbirni/I-letni-vezani-na-razred/9-razred/Retorika_izbirni.pdf (27. II. 2019)

Žmavc, J. (2016) Rhetoric and argumentation as factors in student achievement. In Štremfel, U. (ed.). Student (under)achievement: perspectives, approaches, challenges, pp. 199-222. Ljubljana: Pedagoški inštitut.

Žmavc, J., Cestnik, M., and Žagar, Ž., I. (2018) Posodobitev učnega načrta za obvezni izbirni predmet retorika v osnovni šoli: (predlog). Ljubljana: Pedagoški inštitut. 